\title{
Synthesis, characterization, thermal and spectroscopic studies and bioactivity of complexes of meloxicam with some bivalent transition metals
}

\author{
J. A. Franzé ${ }^{1}$ - T. F. Carvalho ${ }^{1}$ - C. Gaglieri ${ }^{2}$ - F. J. Caires ${ }^{2}$ - G. Bannach ${ }^{2}$ • \\ R. C. Castro ${ }^{3}$ O. Treu-Filho ${ }^{4} \cdot$ M. Ionashiro ${ }^{4}$ R. A. Mendes ${ }^{1}$
}

Received: 13 June 2016/Accepted: 1 December 2016/Published online: 21 December 2016

(C) Akadémiai Kiadó, Budapest, Hungary 2016

\begin{abstract}
Complexes of meloxicam with $\mathrm{Mn}(\mathrm{II}), \mathrm{Co}(\mathrm{II})$, $\mathrm{Ni}(\mathrm{II}), \mathrm{Cu}(\mathrm{II})$ and $\mathrm{Zn}(\mathrm{II})$ were prepared by aqueous precipitation. The compounds were characterized by means of $\mathrm{X}$-ray powder diffractometry, infrared spectroscopy, theoretical calculation, elemental analysis $(\mathrm{CNH})$, differential scanning calorimetry, simultaneous TG/DTG-DTA and evolved gas analysis (EGA). The results obtained from the TG/DTG-DTA curves and elemental analysis made it possible to establish the general formula of these compounds as $\left[\mathrm{M}(\mathrm{Hmel})_{2}\left(\mathrm{H}_{2} \mathrm{O}\right)_{2}\right] n \mathrm{H}_{2} \mathrm{O}$, where $\mathrm{M}=\mathrm{Mn}(\mathrm{II})$, $\mathrm{Co}(\mathrm{II}), \mathrm{Ni}(\mathrm{II}) ; \mathrm{Cu}(\mathrm{II})$ and $\mathrm{Zn}(\mathrm{II}) ; \mathrm{Hmel}=$ meloxicam and $n=2(\mathrm{Mn}, \mathrm{Co}, \mathrm{Ni}, \mathrm{Zn})$ and $1(\mathrm{Cu})$. The simultaneous TG/ DTG-DTA data provided previously unreported information about the thermal stability and thermal decomposition of these compounds in dynamic air and nitrogen atmospheres. The EGA showed the remarkable influence of the atmosphere in the thermal decomposition mechanism of these complexes, and it was also possible to identify the main gaseous products of thermal degradation. The lowest energy model structure of the $\mathrm{Mn}$ (II), Ni(II) and $\mathrm{Zin}(\mathrm{II})$
\end{abstract}

Electronic supplementary material The online version of this article (doi:10.1007/s10973-016-6030-5) contains supplementary material, which is available to authorized users.

R. A. Mendes

roni.mendes@unifal-mg.edu.br

1 Instituto de Ciência e Tecnologia, UNIFAL-MG, Poços de Caldas, MG CEP 37715-400, Brazil

2 Departamento de Química, Faculdade de Ciências, UNESP, Bauru, SP CEP 17033-360, Brazil

3 Centro Universitário de Rio Preto, UNIRP, São José do Rio Preto, SP CEP 15025-400, Brazil

4 Instituto de Química UNESP, CP 355, Araraquara, SP CEP 14801-970, Brazil complexes has been proposed by using the density functional theory at the B3LYP/6-311++G(d) level of theory, and the theoretical spectra were calculated. The antibacterial activity of the compounds was also evaluated in relation to $S$. aureus by the diffusion method in agar, and the compounds showed little activity. The anti-inflammatory activity of the meloxicam-copper complex was also evaluated in vivo by the rat paw edema method. The compound showed no anti-inflammatory activity, which may have been due to loss of intrinsic activity or poor oral absorption caused by low solubility.

Keywords Meloxicam - Transition metals - Thermal behavior · Bioactivity $\cdot$ DFT

\section{Introduction}

NSAIDs (non-steroidal anti-inflammatory drugs) are compounds that are widely used in the symptomatic treatment of inflammatory diseases, such as rheumatoid arthritis; they act by reducing the pain and edema. The mechanism of action of these drugs is the inhibition of the enzyme cyclooxygenase (COX), causing a decrease in the biosynthesis of the prostaglandins (PGs), which are important chemical mediators of inflammation. However, the chronic use of NSAIDs may cause many collateral effects such as gastritis, ulcers, and kidney and liver problems [1].

There are several classes of NSAIDs, and they exhibit different chemical structures. One such class is oxicams (e.g., piroxicam, tenoxicam and meloxicam), which are drugs that were developed in the 1980s by Pfizer $^{\mathrm{TM}}$ [2]. Meloxicam is 4-hydroxy-2-methyl-N-(5-methyl-2-thiazolyl)-2H-1,2-benzothiazine-3-carboxamide-1,1-dioxide [3], and its structure is shown in Fig. 1. 
<smiles>Cc1cnc(NC(=O)C2=C(O)c3ccccc3S(=O)(=O)N2C)s1</smiles>

Fig. 1 Structure of meloxicam drug

In recent years, many complexes of several NSAIDs with metal ions have been synthesized, with the main goal of producing new better drugs with better pharmacokinetics and pharmacodynamics properties, but also to study their chemical characteristics [2-16]. Moreover, some compounds of NSAIDs-metals have showed other pharmacological actions, such as the $\mathrm{Cu}$-diclofenac complex, which presents anti-carcinogenic properties [2]. Complexes of meloxicam have also been synthesized, but previous studies have not focused on the thermal behavior of the compounds produced in the solid state. Additionally, the synthesis of the compounds of the meloxicam in the previous studies used non-aqueous solvent, unlike the present study [11-13].

In the present study, solid compounds of Mn(II), Co (II), $\mathrm{Ni}$ (II), $\mathrm{Cu}$ (II) and $\mathrm{Zn}$ (II) with meloxicam were prepared by aqueous precipitation. The compounds were investigated by means of X-ray powder diffractometry, infrared spectroscopy, differential scanning calorimetry (DSC) and simultaneous thermogravimetry-differential thermal analysis (TG-DTA). The results produced information concerning these compounds in the solid state, including their thermal behavior, stoichiometry and structure. Furthermore, the antibacterial activity of the complexes that were obtained was evaluated by agar diffusion technique in relation to $S$. aureus gram-positive bacteria. The anti-inflammatory activity of the copper complex was evaluated using the model of carrageenan-induced edema in rats.

\section{Experimental}

\section{Materials}

Meloxicam, which was of pharmaceutical purity, was purchased from Fagron, Belgium. The salts of metal ions $\left(\mathrm{MnCl}_{2} \cdot 4 \mathrm{H}_{2} \mathrm{O} ; \mathrm{CoCl}_{2} \cdot 6 \mathrm{H}_{2} \mathrm{O} ; \mathrm{NiCl}_{2} \cdot 6 \mathrm{H}_{2} \mathrm{O} ; \mathrm{CuCl}_{2} \cdot 2 \mathrm{H}_{2} \mathrm{O}\right.$ and $\mathrm{ZnCl}_{2}$ ), which were of analytical grade, were purchased from Dinâmica, Brazil. The chloroform of analytical grade that was used in the antibacterial assay was purchased from Merck, Germany. The norfloxacin used as positive control in the antibacterial assay and the Tween 80 (polysorbate) used in the anti-inflammatory assay were purchased from Fagron, Belgium. The carrageenan used in the anti-inflammatory assay was purchased from Aldrich, USA.

\section{Synthesis of complexes}

For the preparation of these complexes, we used the principles of "green chemistry", thereby avoiding the use of toxic organic solvents, which can remain in the structure of the complex, as has been described previously [12-14]. The ca. $0.100 \mathrm{~mol} \mathrm{~L}^{-1}$ of meloxicam sodium salt aqueous solutions was prepared as follows: $18 \mathrm{~g}$ of meloxicam was weighed and added to distilled water (ca. $50 \mathrm{~mL}$ ). Then $\mathrm{NaOH} 0.100 \mathrm{~mol} \mathrm{~L}^{-1}$ (ca. $50 \mathrm{~mL}$ ) was added with continuous stirring. The resulting suspension was fully dissolved by the addition of more distilled water. The volume was completed to $500 \mathrm{~mL}$.

The aqueous solutions of manganese, cobalt, nickel, cooper and zinc chloride were obtained by direct weighing of the respective salts and dissolution in distilled water.

To prepare the complexes was used solution of Nameloxicam was in stoichiometric excess of ca. 50\% and its initial $\mathrm{pH}$ was adjusted to 8.5 . The Na-meloxicam solution was added slowly, with continuous stirring, to the respective metallic ion solution until total precipitation of the metal ions. The precipitates obtained were vacuum filtered and washed with distilled water until the elimination of chloride and kept in a desiccator over anhydrous calcium chloride until constant weight.

\section{Experimental equipment and conditions}

The carbon, hydrogen and nitrogen contents were determined by microanalytical procedures using a CHN Elemental Analyzer from Perkin Elmer, (model 2400) and also by calculations based on the mass losses of the TG curves.

The X-ray powder patterns were obtained by using a Siemens D-5000 X-Ray diffractometer employing $\mathrm{Cu} \mathrm{Ka}$ radiation $(\lambda=1.541 \AA$ ) and settings of $40 \mathrm{kV}$ and $20 \mathrm{~mA}$.

The attenuated total reflectance infrared spectra were run on a Nicolet iS10 Fourier transform infrared spectrophotometer (FTIR) using an ATR accessory with Ge window. The FTIR spectra were recorded in the region of $4000-700 \mathrm{~cm}^{-1}$ with 32 scans per spectrum at a resolution of $4 \mathrm{~cm}^{-1}$.

For the analyzed complexes, the contents of hydration water, ligand and metal were determined from the TGDTA curves that were obtained using a simultaneous thermal analysis system, model SDT 2960, from TA Instruments. The purge gases were air or $\mathrm{N}_{2}$, with a flow rate of $100 \mathrm{~mL} \mathrm{~min}{ }^{-1}$. A heating rate of $20{ }^{\circ} \mathrm{C} \mathrm{min}^{-1}$ was adopted, with samples weighing about $5 \mathrm{mg}$, and alumina crucible were used to record the TG-DTA curves. 
The DSC curves were obtained by using a thermal analysis system, model DSC Q10, from TA Instruments. The purge gas was nitrogen with a flow rate of $50 \mathrm{~mL} \mathrm{~min}{ }^{-1}$. A heating rate of $10{ }^{\circ} \mathrm{C} \min ^{-1}$ was adopted, with samples weighing about $2 \mathrm{mg}$ into an aluminum crucible with perforated cover.

The measurements of the gaseous products were carried out using a Mettler Toledo TG-DSC coupled to a Nicolet FTIR spectrophotometer, with gas cell and DTGS $\mathrm{KBr}$ detector. The furnace and the heated gas cell $\left(250^{\circ} \mathrm{C}\right)$ were coupled through a heated $\left(225^{\circ} \mathrm{C}\right) 120 \mathrm{~cm}$ stainless steel line transfer with diameter of $3 \mathrm{~mm}$, both purged with dry air or $\mathrm{N}_{2}\left(50 \mathrm{~mL} \mathrm{~min}^{-1}\right)$. The FTIR spectra were recorded in the region of $4000-400 \mathrm{~cm}^{-1}$ with 16 scans per spectrum at a resolution of $4 \mathrm{~cm}^{-1}$.

\section{Computational strategy}

In this study, the quantum chemical approach employed to determine the molecular structures was Becke's three-parameter hybrid theory [17] using the Lee-Yang-Parr (LYP) functional correlation [18], and the basis sets used for the calculations were $6-311++\mathrm{G}(\mathrm{d})[19,20]$. The molecular calculations in this study were performed using the Gaussian 09 routine [21]. The theoretical infrared spectra were calculated using a harmonic field [22] based on $\mathrm{C} 1$ symmetry (electronic state 1A). The frequency values (not scaled), relative intensities, assignments, and descriptions of the vibrational modes are presented. The geometry optimization was computed using the Berny optimization algorithm [23], and the calculations of the vibrational frequencies were also implemented to determine an optimized geometry constituting minimum or saddle points. The principal infrared active fundamental mode assignments and descriptions were performed using the GaussView 5.0.2 $\mathrm{W}$ graphics routine $[24,25]$.

\section{Biological assays}

Testing for antimicrobial activity was performed by the agar diffusion method. Initial solutions of the complexes and meloxicam drug, with a concentration $2 \mathrm{mg} \mathrm{mL}^{-1}$ were prepared using chloroform as the solvent. Solutions with concentrations of 50 and $100 \mu \mathrm{g} \mathrm{mL}{ }^{-1}$ were obtained by dilution. Filter paper disks, $5 \mathrm{~mm}$ in diameter, were immersed in $2 \mathrm{~mL}$ dilute solutions of the compounds and maintained until the complete evaporation of the solvent. A bacterial suspension of $S$. aureus in distilled water was prepared with turbidity equivalent to 0.5 on the McFarland scale (c.a. $1.5 \times 10^{8}$ bacterial cells $\mathrm{mL}^{-1}$ ). A quantity of $100 \mu \mathrm{L}$ of the suspension was inoculated into Petri plates containing LB agar and after drying for $5 \mathrm{~min}$ in oven at $35^{\circ} \mathrm{C}$, the paper disks were placed on Petri plates at a distance of $5 \mathrm{~cm}$ from each other. Saturated paper disks with a chloroform solution of norfloxacin $20 \mu \mathrm{g} \mathrm{mL}^{-1}$ were used as positive control. The Petri plates were incubated at $30{ }^{\circ} \mathrm{C}$ for $18 \mathrm{~h}$. The measurements of the inhibition zones of bacterial growth were performed with a caliper. The experiment was repeated in triplicate.

The anti-inflammatory activity of the copper-meloxicam complex was evaluated using the model of carrageenaninduced edema in rats (approved by Ethics Committee, protocol CEUA-UNIRP, number: 16/2013). For this purpose, we used male Wistar rats, 2 months old, weighing $180-200 \mathrm{~g}$. The rats were randomly divided into groups of six animals each. The method of drug administration was oral (p.o). The first group (control) received vehicle only. The second group (positive control) received meloxicam suspended in a dosage of $4 \mathrm{mg} \mathrm{kg}^{-1}$. The third group received a suspension of the copper-meloxicam ( $4 \mathrm{mg} \mathrm{kg}^{-1}$ ) complex. The vehicle used was a mixture of aqueous solution of Tween $80(8 \% \mathrm{~m} / \mathrm{v})$ and carboxymethylcellulose $(1 \% \mathrm{~m} / \mathrm{v})$. One hour after the administration of the drug, carrageenan $\left(10 \mathrm{mg} \mathrm{mL}^{-1}\right)$ was applied by subplantar injection in the left posterior paw of each animal. The paw volume was measured using a plethysmometer (Ugo Basile, Model 37140). The results were compared statistically according to analysis of variance (ANOVA) followed by Tukey's test for multiple comparisons using ORIGIN software, version 7.0. $P$ values equal to or less than 0.05 were considered significant.

\section{Results and discussion}

\section{Analytical results}

The obtained compounds had the following colors: $\mathrm{Mn}$ (yellow), Co (orange), $\mathrm{Ni}$ (green), $\mathrm{Cu}$ (olive) and $\mathrm{Zn}$ (light yellow).The analytical results for the synthesized compounds are shown in Table 1. All the data are in excellent agreement, suggesting that the compounds that were obtained had excellent purity. These results made it possible to calculate the stoichiometry of the compounds, which is in agreement with the general formula $\left[\mathrm{M}(\mathrm{Hmel})_{2}\left(\mathrm{H}_{2} \mathrm{O}\right)_{2}\right] n \mathrm{H}_{2} \mathrm{O}$, where $\mathrm{M}=\mathrm{Mn}(\mathrm{II}), \quad \mathrm{Co}(\mathrm{II})$, $\mathrm{Ni}(\mathrm{II}) ; \mathrm{Cu}(\mathrm{II})$ and $\mathrm{Zn}(\mathrm{II}) ; \mathrm{Hmel}=$ meloxicam and $n=2$ (Mn, $\mathrm{Co}, \mathrm{Ni}, \mathrm{Zn})$ and $1(\mathrm{Cu})$.

\section{Thermal analysis}

The TG/DTG-DTA curves of the synthesized compounds are shown in Fig. 2. These curves show that all the compounds are obtained in the hydrated state and that the thermal decomposition occurs in overlapping steps in both atmospheres (air and $\mathrm{N}_{2}$ ), corresponding to the 


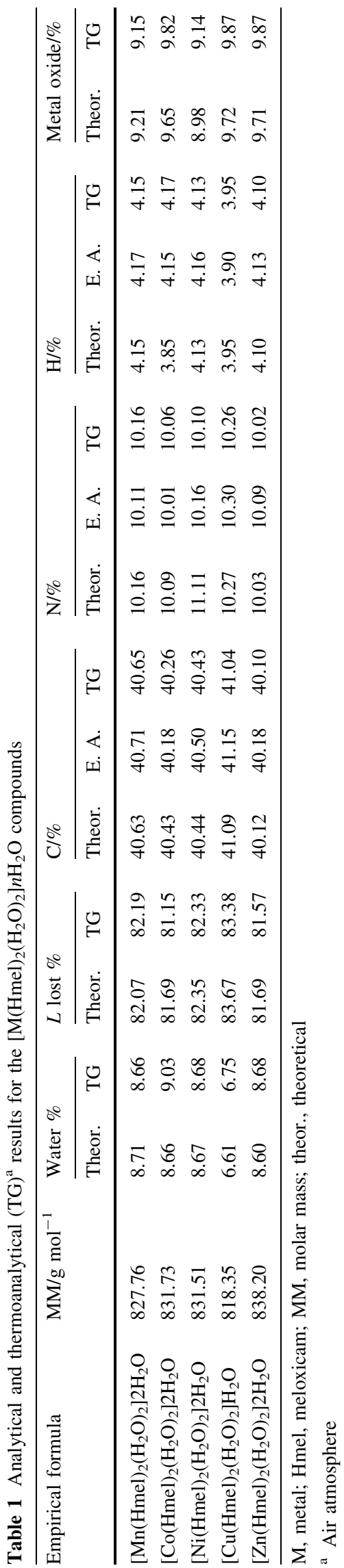

endothermic peaks due to dehydration or pyrolysis of the anhydrous compounds, and the exothermic peaks, which are attributed to oxidation of the organic matter.

These curves also show that the thermal stability of the compounds depends on the nature of the metal ion and they follow the subsequent order:

$$
\begin{aligned}
\mathrm{Ni}>\mathrm{Mn}>\mathrm{Co}>\mathrm{Zn}>\mathrm{Cu}(\text { air }) \\
\mathrm{Ni} \approx \mathrm{Co}>\mathrm{Mn}>\mathrm{Zn}>\mathrm{Cu}\left(\mathrm{N}_{2}\right)
\end{aligned}
$$

The mass losses $(\Delta m)$, temperature ranges $(\theta)$ and peak temperatures $\left(T_{\mathrm{P}}\right)$ observed for each step of the TG/DTGDTA curves are shown in Table 2.

\section{TG/DTG-DTA in air atmosphere}

The simultaneous TG/DTG-DTA curves of the compounds analyzed in air atmosphere are shown in Fig. 2a-e. These curves exhibit mass losses in four $(\mathrm{Ni}, \mathrm{Cu}, \mathrm{Zn})$ or five (Mn, Co) steps and thermal events corresponding to these losses, although the DTG curves suggest much more complex steps.

The first mass loss for the compounds occurs at temperature ranges of $323-428,318-438 ; 313-428 ; 303-383$ and $303-423 \mathrm{~K}$, respectively, for $\mathrm{Mn}, \mathrm{Co}, \mathrm{Ni}, \mathrm{Cu}$ and $\mathrm{Zn}$ compounds. These first mass losses are attributed to dehydration of the compounds. After dehydration, the mass losses observed for all the compounds are due to the thermal decomposition of the anhydrous compounds. These take place in consecutive and/or overlapping steps with partial losses, which are characteristic for each compound and without the formation of any thermally stable intermediate.

For the manganese anhydrous compounds, the mass losses up to $893 \mathrm{~K}$, which correspond to exothermic peaks, are attributed to the oxidation of the organic matter, with the formation of $\mathrm{Mn}_{2} \mathrm{O}_{3}$ in a mixture with carbonaceous residue. The last mass loss step is observed between 978 and $1068 \mathrm{~K}$ and is attributed to the slow oxidation of charred residue, which leads to the formation of $\mathrm{Mn}_{3} \mathrm{O}_{4}$ as final residue (theor. $=9.21 \%$; $\mathrm{TG}=9.15 \%$ ), in agreement with the results described in Ref [26].

For the cobalt anhydrous compounds, the mass losses up to $848 \mathrm{~K}$, which correspond to exothermic peaks, are attributed to the oxidation of the organic matter, with the formation of $\mathrm{Co}_{3} \mathrm{O}_{4}$ (theor. $=9.65 \%$; $\mathrm{TG}=9.82 \%$ ). The last mass loss step observed for this compound occurs between 1183 and $1213 \mathrm{~K}$ and corresponds to an endothermic peak, with the reduction of $\mathrm{Co}_{2} \mathrm{O}_{3}$ to $\mathrm{CoO}$ as final residue, in agreement with results described in Ref [27].

For the other anhydrous compounds, the thermal decomposition with oxidation of the organic matter occurs up to $833(\mathrm{Ni}), 908(\mathrm{Cu})$ or $943 \mathrm{~K}(\mathrm{Zn})$ and corresponds to 


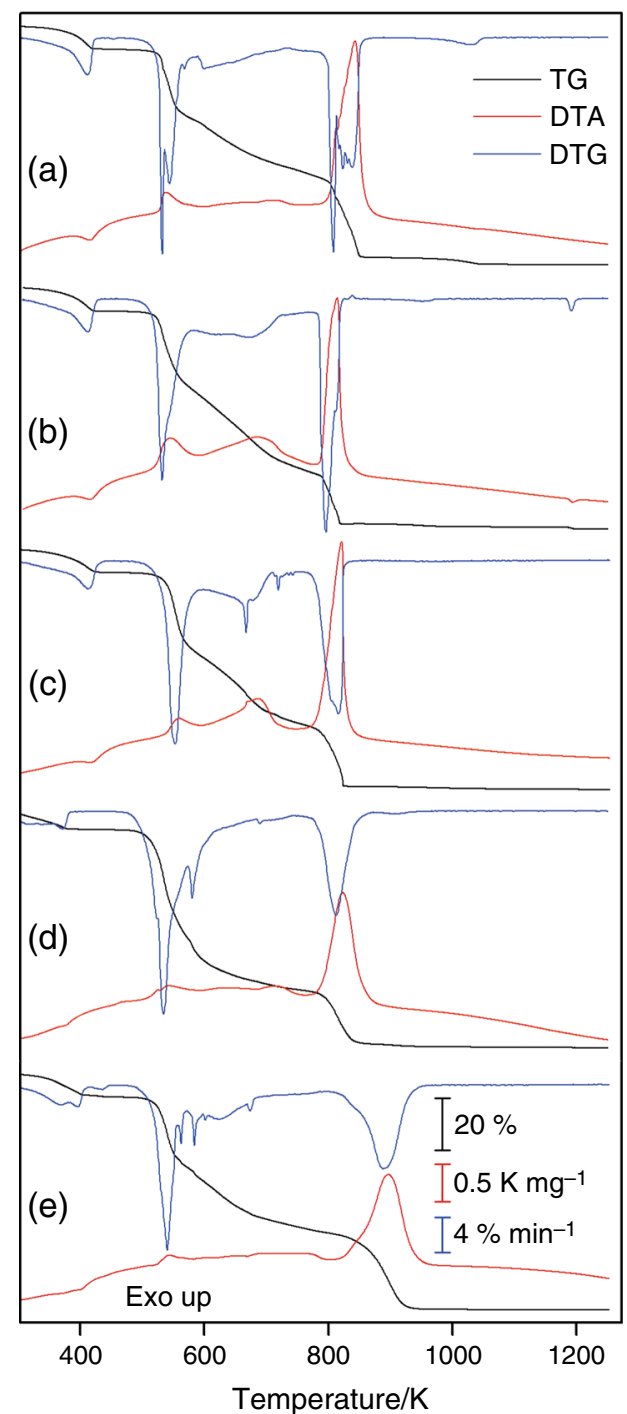

Fig. 2 TG/DTG-DTA curves of the compounds in air atmosphere ( $a-$ $e)$ or $\mathrm{N}_{2}\left(a^{*}-e^{*}\right):\left[\mathrm{Mn}(\mathrm{Hmel})_{2}\left(\mathrm{H}_{2} \mathrm{O}\right)_{2}\right] 2 \mathrm{H}_{2} \mathrm{O}-a(5.3661 \mathrm{mg})$ or $a^{*}$ $(5.4001 \mathrm{mg}) ;\left[\mathrm{Co}(\mathrm{Hmel})_{2}\left(\mathrm{H}_{2} \mathrm{O}\right)_{2}\right] 2 \mathrm{H}_{2} \mathrm{O}-b(5.3569 \mathrm{mg})$ or $b *(5.3661$

exothermic peaks, with the formation of the respective oxides $(\mathrm{NiO}, \mathrm{CuO}$ or $\mathrm{ZnO})$ as final residue.

\section{TG/DTG-DTA in $N_{2}$ atmosphere}

The simultaneous TG/DTG-DTA curves of the compounds analyzed in $\mathrm{N}_{2}$ atmosphere are shown in Fig. $2 \mathrm{a}^{*}-\mathrm{e}^{*}$. The first mass loss for the compounds of $\mathrm{Mn}, \mathrm{Co}, \mathrm{Ni}, \mathrm{Cu}$ and $\mathrm{Zn}$ is found at temperatures ranges of 323-428, 318-428, 313-438, 303-383 and 303-438 K, respectively. These mass losses are attributed to the dehydration of the compounds, and they are consistent with the first mass loss observed in the TG/DTG-DTA curves in air atmosphere. However, the mass losses observed during the first stage of

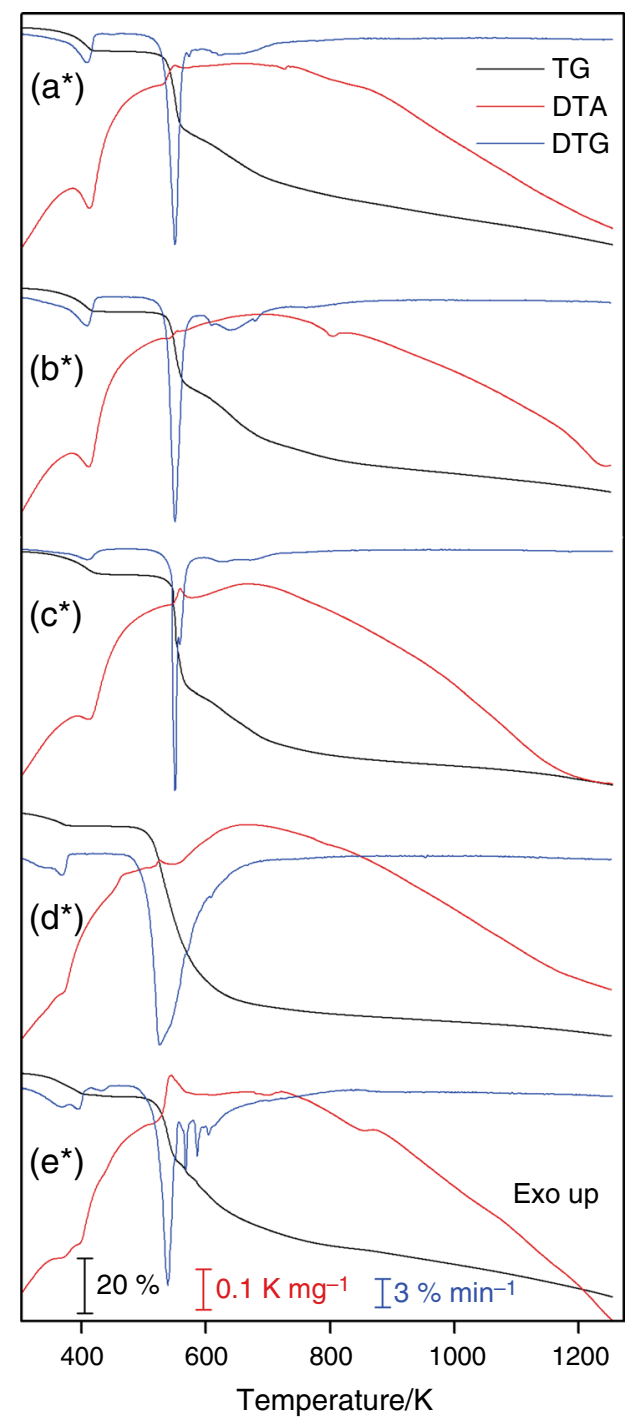

$\mathrm{mg}) ;\left[\mathrm{Ni}(\mathrm{Hmel})_{2}\left(\mathrm{H}_{2} \mathrm{O}\right)_{2}\right] 2 \mathrm{H}_{2} \mathrm{O}-c(5.4083 \mathrm{mg})$ or $c^{*}(5.3593 \mathrm{mg})$; $\left[\mathrm{Cu}(\mathrm{Hmel})_{2}\left(\mathrm{H}_{2} \mathrm{O}\right)_{2}\right] \mathrm{H}_{2} \mathrm{O}-d \quad(5.4030 \mathrm{mg}) \quad$ or $d^{*}(5.3622 \mathrm{mg})$; $\left[\mathrm{Zn}(\mathrm{Hmel})_{2}\left(\mathrm{H}_{2} \mathrm{O}\right)_{2}\right] 2 \mathrm{H}_{2} \mathrm{O}-e(5.3273 \mathrm{mg})$ or $e^{*}(5.4347 \mathrm{mg})$

thermal decomposition in the TG-DTA curves in $\mathrm{N}_{2}$ atmosphere are slightly smaller than those observed in air atmosphere. This may have occurred because the system is purged with nitrogen gas for about 20 min before the start of the recording of the curves, which probably dragged part of the water that was weakly bound in the compounds. The mass losses observed for all the compounds after dehydration are due to the thermal decomposition of anhydrous compounds, but the pyrolysis of the organic matter was not complete and this generates the mixture of metallic oxides with carbonaceous residues. The number of steps of mass loss observed in the TG/DTG-DTA curves in $\mathrm{N}_{2}$ atmosphere is less than the number observed in the TG-DTA curves in air atmosphere. An interesting detail that is 
Table 2 Temperature ranges $(\theta)$, mass losses $(\Delta m)$ and peak temperatures $\left(T_{\mathrm{p}}\right)$ observed for each step of the TG/DTG-DTA curves of the $\left[\mathrm{M}(\mathrm{Hmel})_{2}\left(\mathrm{H}_{2} \mathrm{O}\right)_{2}\right] n \mathrm{H}_{2} \mathrm{O}$ compounds

\begin{tabular}{|c|c|c|c|c|c|c|c|c|c|c|c|c|}
\hline \multirow[t]{3}{*}{ Compounds } & \multicolumn{10}{|l|}{ Steps } & \multicolumn{2}{|c|}{ Total $\Delta m$} \\
\hline & \multicolumn{2}{|l|}{ First } & \multicolumn{2}{|l|}{ Second } & \multicolumn{2}{|l|}{ Third } & \multicolumn{2}{|l|}{ Fourth } & \multicolumn{2}{|l|}{ Fifth } & \multirow[t]{2}{*}{ Air } & \multirow[t]{2}{*}{$\mathrm{N}_{2}$} \\
\hline & Air & $\mathrm{N}_{2}$ & Air & $\mathrm{N}_{2}$ & Air & $\mathrm{N}_{2}$ & Air & $\mathrm{N}_{2}$ & Air & $\mathrm{N}_{2}$ & & \\
\hline \multicolumn{13}{|c|}{$\left[\mathrm{Mn}(\mathrm{Hmel})_{2}\left(\mathrm{H}_{2} \mathrm{O}\right)_{2}\right] 2 \mathrm{H}_{2} \mathrm{O}$} \\
\hline$\theta / \mathrm{K}$ & $323-428$ & $323-428$ & $508-573$ & $508-563$ & $573-795$ & $563-733$ & $795-893$ & $733-1253$ & $978-1068$ & - & 90.85 & 78.47 \\
\hline$\Delta m / \%$ & 8.66 & 8.55 & 25.80 & 28.22 & 24.20 & 20.57 & 29.68 & 21.53 & 2.51 & & & \\
\hline$T_{\mathrm{p}} / \mathrm{K}$ & $414 \downarrow$ & $411 \downarrow$ & $539 \uparrow$ & $549 \uparrow$ & $713 \uparrow$ & $726 \downarrow$ & $843 \uparrow$ & - & - & & & \\
\hline \multicolumn{13}{|c|}{$\left[\mathrm{Co}(\mathrm{Hmel})_{2}\left(\mathrm{H}_{2} \mathrm{O}\right)_{2}\right] 2 \mathrm{H}_{2} \mathrm{O}$} \\
\hline$\theta / \mathrm{K}$ & $318-438$ & $318-428$ & $503-578$ & $518-573$ & $578-758$ & $573-698$ & $758-848$ & $698-1253$ & $1183-1213$ & - & 90.18 & 74.00 \\
\hline$\Delta m / \%$ & 9.03 & 8.52 & 29.34 & 26.89 & 31.08 & 19.64 & 20.73 & 18.95 & 1.98 & & & \\
\hline$T_{\mathrm{p}} / \mathrm{K}$ & $415 \downarrow$ & $412 \downarrow$ & $544 \uparrow$ & $540 \uparrow / 553 \uparrow$ & $688 \uparrow$ & & $813 \uparrow$ & $803 \downarrow$ & $1193 \downarrow$ & & & \\
\hline \multicolumn{13}{|c|}{$\left[\mathrm{Ni}(\mathrm{Hmel})_{2}\left(\mathrm{H}_{2} \mathrm{O}\right)_{2}\right] 2 \mathrm{H}_{2} \mathrm{O}$} \\
\hline$\theta / \mathrm{K}$ & $313-428$ & $313-438$ & $513-583$ & $518-573$ & $583-748$ & $573-698$ & $748-833$ & $698-1253$ & - & - & 90.85 & 84.56 \\
\hline$\Delta m / \%$ & 8.68 & 8.56 & 29.68 & 41.01 & 27.63 & 18.59 & 24.86 & 16.40 & & & & \\
\hline$T_{\mathrm{p}} / \mathrm{K}$ & $418 \downarrow$ & $413 \downarrow$ & $560 \uparrow$ & $558 \uparrow$ & $688 \uparrow$ & - & $820 \uparrow$ & - & & & & \\
\hline \multicolumn{13}{|c|}{$\left[\mathrm{Cu}(\mathrm{Hmel})_{2}\left(\mathrm{H}_{2} \mathrm{O}\right)_{2}\right] \mathrm{H}_{2} \mathrm{O}$} \\
\hline$\theta / \mathrm{K}$ & $303-383$ & $303-383$ & $483-613$ & $483-638$ & $613-768$ & $638-1253$ & $768-908$ & - & - & - & 90.13 & 85.99 \\
\hline$\Delta m / \%$ & 6.75 & 4.83 & 52.69 & 62.27 & 9.25 & 14.01 & 21.44 & & & & & \\
\hline$T_{\mathrm{p}} / \mathrm{K}$ & $377 \downarrow$ & - & $542 \uparrow$ & $523 \uparrow$ & $713 \uparrow$ & - & $823 \uparrow$ & & & & & \\
\hline \multicolumn{13}{|c|}{$\left[\mathrm{Zn}(\mathrm{Hmel})_{2}\left(\mathrm{H}_{2} \mathrm{O}\right)_{2}\right] 2 \mathrm{H}_{2} \mathrm{O}$} \\
\hline$\theta / \mathrm{K}$ & $303-423$ & $303-438$ & $498-553$ & $498-798$ & $553-798$ & $798-1253$ & $798-943$ & - & - & - & 90.13 & 81.34 \\
\hline$\Delta m / \%$ & 8.73 & 8.53 & 22.41 & 23.22 & 29.43 & 49.53 & 29.42 & & & & & \\
\hline$T_{\mathrm{p}} / \mathrm{K}$ & $370,401 \downarrow$ & $368,396 \downarrow$ & $543 \uparrow$ & $519 \downarrow / 543 \uparrow$ & $773 \uparrow$ & - & $898 \uparrow$ & & & & & \\
\hline
\end{tabular}

Hmel, meloxicam; $\uparrow$, exo; $\downarrow$, endo

observed in the TG/DTG-DTA curves in nitrogen atmosphere is that the temperature at which the decomposition of the anhydrous compounds begins is close to the temperature observed in the TG-DTA curves in air atmosphere. This fact makes it possible to suggest that the type of atmosphere (inert or oxidant) does not have great influence on the thermal stability of these compounds. However, the type of atmosphere can influence the mechanism of thermal decomposition of the compounds, this is confirmed by the EGA results, which will be presented and discussed below.

The formation of the respective oxides as final residue in the thermal decomposition of the compounds in air and $\mathrm{N}_{2}$ atmospheres are based on the total mass losses of the TG curves, and it was also experimentally verified on the basis on their X-ray diffraction powder patterns.

\section{$D S C$}

The DSC curves of the compounds are shown in Fig. 3a-e. The endothermic peaks at $430(\mathrm{Mn}), 429$ (Co), 423 (Ni), $390(\mathrm{Cu})$ and $391,414 \mathrm{~K}(\mathrm{Zn})$ are attributed to dehydration and are in agreement with the first mass loss observed in the TG-DTA curves. The dehydration enthalpy found for these compounds are 222.7, 200.9, 198.1, 21.23 and $192 \mathrm{~kJ} \mathrm{~mol}^{-1}$, respectively.

The exothermic peak at $458 \mathrm{~K}$, which is observed only for the copper compound, without mass loss in the TG, suggests a phase transitions, as can be seen in Fig. 4.

\section{$E G A$}

The analysis of the gases that are produced during the decomposition process can provide valuable information about the pathway of decomposition. The three-dimensional diagrams (3D) corresponding to the gases which evolved in the thermal decomposition of the manganese complex are shown in Fig. 5. They show the absorbance corresponding to the vibrational modes of the different chemical bonds and functional groups versus the wavenumber and versus the time. They provide a clear qualitative picture of the overall information for the evolution of the FTIR spectra.

The Gram-Schmidt (GS) curves and FTIR spectra of the gaseous products, at different temperatures of the thermal decomposition of the manganese complex are shown in Fig. 6 (air and $\mathrm{N}_{2}$ atmosphere). They are representative of 


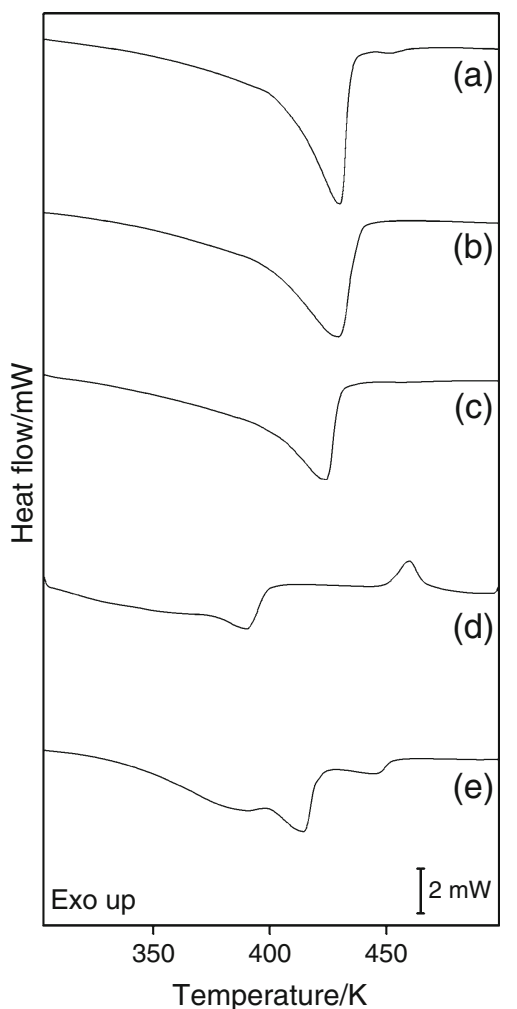

Fig. 3 DSC curves of the compounds in $\mathrm{N}_{2}$ atmosphere: $a\left[\mathrm{Mn}(\mathrm{Hmel})_{2}\left(\mathrm{H}_{2} \mathrm{O}\right)_{2}\right] 2 \mathrm{H}_{2} \mathrm{O} ; b\left[\mathrm{Co}(\mathrm{Hmel})_{2}\left(\mathrm{H}_{2} \mathrm{O}\right)_{2}\right] 2 \mathrm{H}_{2} \mathrm{O} ; c\left[\mathrm{Ni}(\mathrm{Hmel})_{2}\right.$ $\left.\left(\mathrm{H}_{2} \mathrm{O}\right)_{2}\right] 2 \mathrm{H}_{2} \mathrm{O} ; d\left[\mathrm{Cu}(\mathrm{Hmel})_{2}\left(\mathrm{H}_{2} \mathrm{O}\right)_{2}\right] \mathrm{H}_{2} \mathrm{O} ; e\left[\mathrm{Zn}(\mathrm{Hmel})_{2}\left(\mathrm{H}_{2} \mathrm{O}\right)_{2}\right] 2 \mathrm{H}_{2} \mathrm{O}$

all the complexes because the released gases are the same. The GS curves show that the thermal decomposition in an oxidizing atmosphere (air) follows a more complex path than in inert atmosphere $\left(\mathrm{N}_{2}\right)$, in accordance with the DTG curves. Furthermore, based on reference FTIR spectra available in the software of the spectrometer, it is possible to suggest the main gaseous products that are released during the thermal decomposition in both atmospheres, as follows.

In terms of air atmosphere, the main gas products identified are water (dehydration), sulfur dioxide $\left(\mathrm{SO}_{2}\right)$, carbonyl sulfide (COS), methyl isocyanate $\left(\mathrm{C}_{2} \mathrm{H}_{3} \mathrm{NO}\right)$ and ammonia $\left(\mathrm{NH}_{3}\right)$. In terms of nitrogen atmosphere, the main gaseous products are $\mathrm{H}_{2} \mathrm{O}$ (dehydration), $\mathrm{CO}_{2}, \mathrm{C}_{2} \mathrm{H}_{3} \mathrm{NO}$, COS, $\mathrm{NH}_{3}$, 2-amino-4-methylthiazole $\left(\mathrm{C}_{4} \mathrm{H}_{6} \mathrm{~N}_{2} \mathrm{~S}\right)$, hydrogen cyanide ( $\mathrm{HCN})$ and isocyanic acid ( $\mathrm{HNCO}$ ). Bands are also observed in the stretching region of the carbonyl group $(\vee \mathrm{C}=\mathrm{O})$ and the aromatic $\mathrm{C}-\mathrm{H}$ stretch $(\nu \mathrm{C}-\mathrm{H})$ [28]. From these results, it is evident that there is a greater variety of gaseous products released in the nitrogen atmosphere than in the air atmosphere, showing the remarkable influence of the atmosphere on the thermal decomposition mechanism of these compounds, as is also observed in the TG/DTGDTA curves.

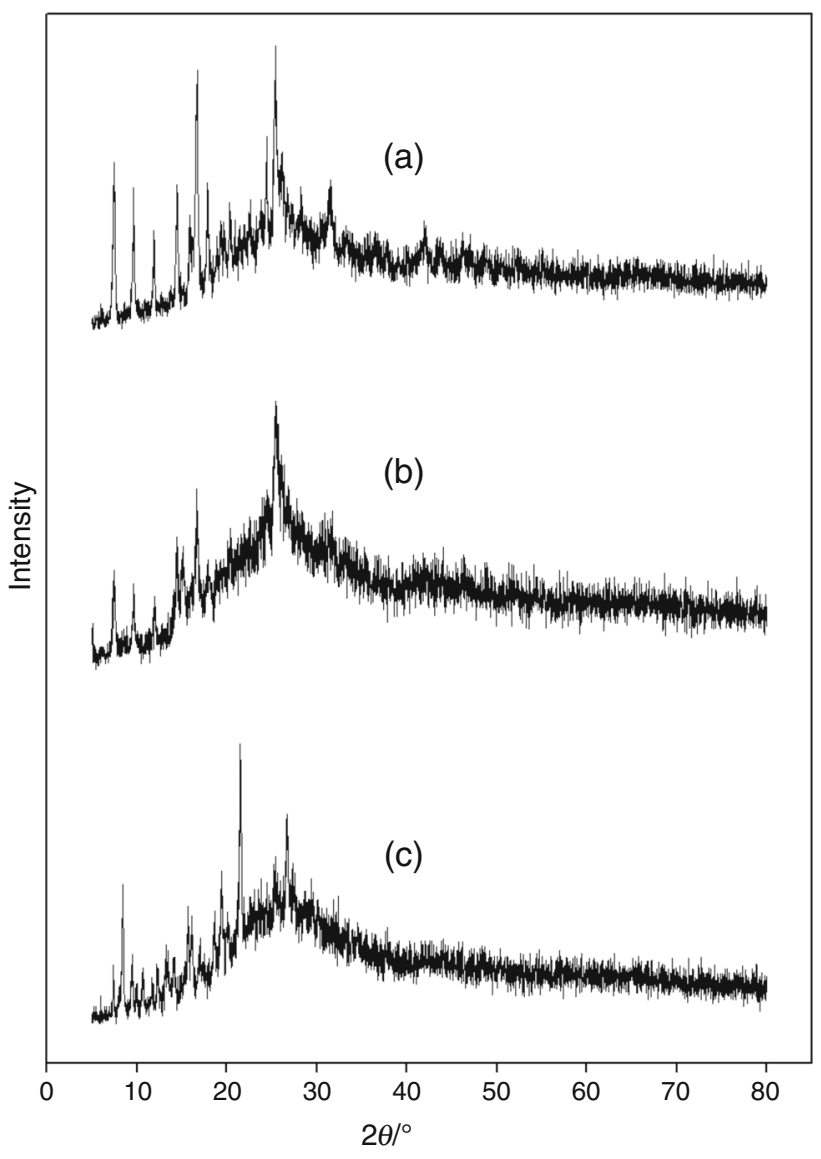

Fig. 4 X-ray powder diffraction patterns of: $a\left[\mathrm{Cu}(\mathrm{Hmel})_{2}\left(\mathrm{H}_{2} \mathrm{O}\right)_{2}\right]$ $\mathrm{H}_{2} \mathrm{O} ; b \mathrm{Cu}(\mathrm{Hmel})_{2}$ heated to $160{ }^{\circ} \mathrm{C} ; c \mathrm{Cu}(\mathrm{Hmel})_{2}$ heated to $205^{\circ} \mathrm{C}$

\section{Infrared vibrational spectroscopy and theoretical calculations}

The proposed structures of the compounds in order to perform the theoretical calculation (optimization of geometry and theoretical infrared spectrum) using the B3LYP method and basis set $6-311++\mathrm{G}(\mathrm{d})$ are based on studies of the structural determination of related compounds [12-14]. The optimized structures are presented in Fig. 7, and the values of the lengths and angle bonds in the coordination sphere are presented in supplementary material (Table S1). These theoretical results are in good agreement with literature data for similar complexes [12-14].

Furthermore, the calculated infrared spectra are very similar to the experimental spectra (supplementary material, Fig. S1), suggesting that the optimized geometry is close to the real geometry. The differences observed between the theoretical and experimental results are related to the fact that the theoretical calculations do not include the anharmonic effects in the vibrations of the $\mathrm{C}-\mathrm{H}, \mathrm{N}-\mathrm{H}$ and $\mathrm{O}-\mathrm{H}$ bonds [29-31]. Most of the discrepancies for the 

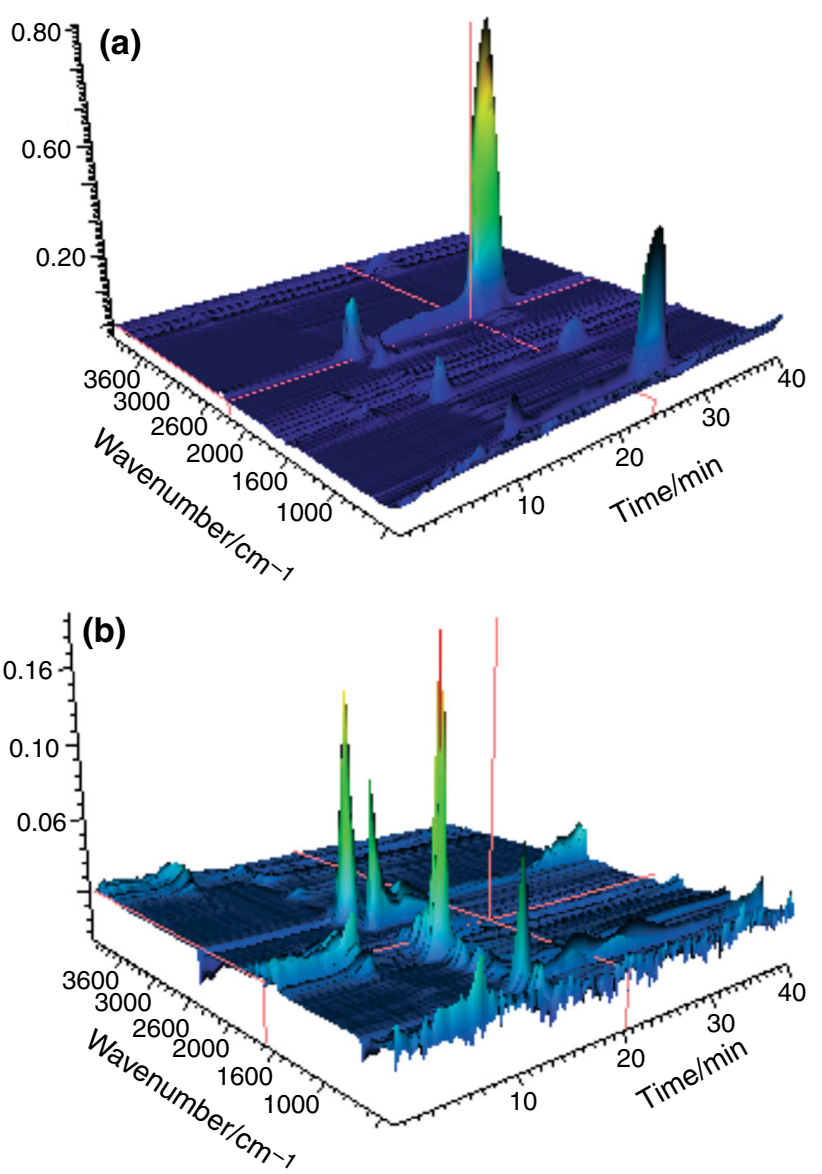

Fig. 5 The 3D FTIR spectra in air (a) and nitrogen atmosphere (b) of the compound of manganese, as representative of all compounds

other vibrations arise from the approximate nature of the computational technique that is used and probably also from the lattice effects in the substance studied as a solid, while the theoretical calculations pertain to the gaseous phase $[30,32]$. The theoretical spectra are also used to perform assignments of the main vibrational modes observed in the experimental spectra (Table 3).

The analysis of the experimental IR spectra (Fig. S1) shows that the spectra of the $\mathrm{Mn}, \mathrm{Co}, \mathrm{Ni}$ and $\mathrm{Zn}$ compounds are very similar, suggesting that the ligands bound to the metal center in the same way and are isostructural, in accordance with the results of the theoretical calculations and the XRD analysis, which has also been observed in similar metal complexes [12-14]. In the copper complex, the bands associated with water molecules are different and the band assigned to the $\mathrm{N}-\mathrm{H}$ stretch is observed, suggesting that in this complex the water molecules must have participated in different interactions with the ligands and/or the central ion metallic and/or a smaller number of hydrogen bonds because smaller amount of water of hydration. The spectrum of the dehydrated copper compound (which was heated to $205{ }^{\circ} \mathrm{C}$ ) shows the disappearance of the $v \mathrm{O}-\mathrm{H}$ bands, confirming that the assignments made for these bands are correct (supplementary material).

Compared to the free ligand $\left(\mathrm{H}_{2} \mathrm{Mel}\right)$, the frequencies related to the vibrational band modes $\mathrm{NH}$ (amide II band), $\mathrm{C}=\mathrm{O}$ stretching (amide I band) and stretching thiazole ring in the compounds are more overlapped and shifted to the lower frequency region, confirming that these are the coordination sites, as suggested by the theoretical calculations. Consequently, the two $\mathrm{Hmel}^{-}$anions chelate the metal center through the nitrogen atom from the thiazole ring and the amide oxygen atom, whereas the two $\mathrm{H}_{2} \mathrm{O}$ molecules link the metal through their oxygen atoms.

\section{X-ray diffractometry}

The X-ray powder patterns, the calculated values for $2 \theta$, $d h k l$, and the relative intensities of the diffraction peaks are provided in supplementary material (Fig. S2 and Table S2). The X-ray powder pattern show that all the compounds have a crystalline structure and only $\mathrm{Mn}, \mathrm{Co}$ and $\mathrm{Zn}$ provide evidence for the formation of isomorphous compounds, and the crystallinity of these compounds follows the order: $\mathrm{Mn}>\mathrm{Cu}>\mathrm{Co} \approx \mathrm{Zn}>$ Ni. The difference in the crystallinity of these compounds must be due to the precipitation conditions, which were not controlled.

\section{Bioactivity}

Bacterial resistance to antibiotics is a worldwide health problem and the search for new drugs is very important. The antibacterial activity of metal complexes of NSAIDs has been observed in some studies [33-37]. In the present study, in order to perform a scan of the antibacterial activity of the complexes in relation to $S$. aureus, concentrations of 50 and $100 \mu \mathrm{g} \mathrm{mL}^{-1}$ are used in the tests. Although the tested concentrations are high, the results show that the antibacterial activity of the analyzed complexes is very small. Most of the disks do not produce large halos of inhibition of bacterial growth. A few paper disks generate very small halos, but significantly less than the norfloxacin used as positive control. However, it should be emphasized that the disks impregnated with meloxicam do not show inhibition zones in any situation. Thus, it is possible to suggest that the meloxicam complexes that were studied have greater antibacterial activity than meloxicam, but they do not have the potential for clinical antibacterial use because plasma concentrations of meloxicam greater than $1 \mu \mathrm{g} \mathrm{mL}^{-1}$ increase the occurrence of side effects. For comparison, in another study of the metal complexes of lornoxicam (which is analogous to meloxicam) [33], the antibacterial activity of the 

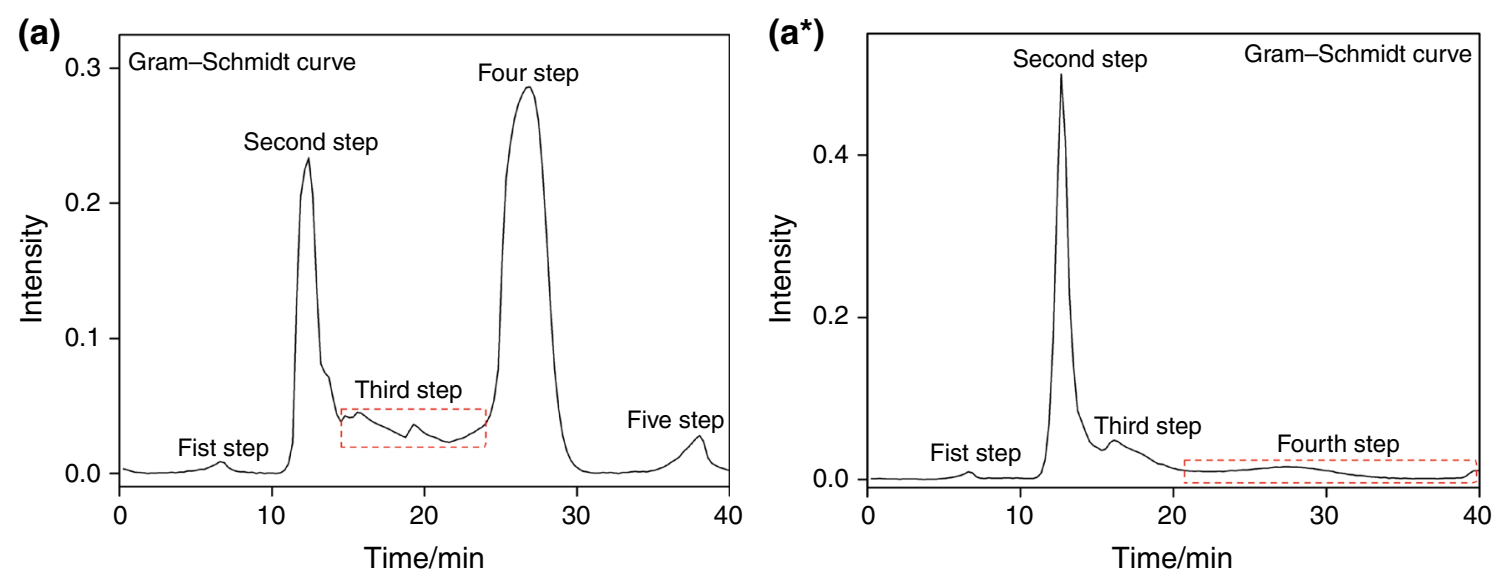

(b)

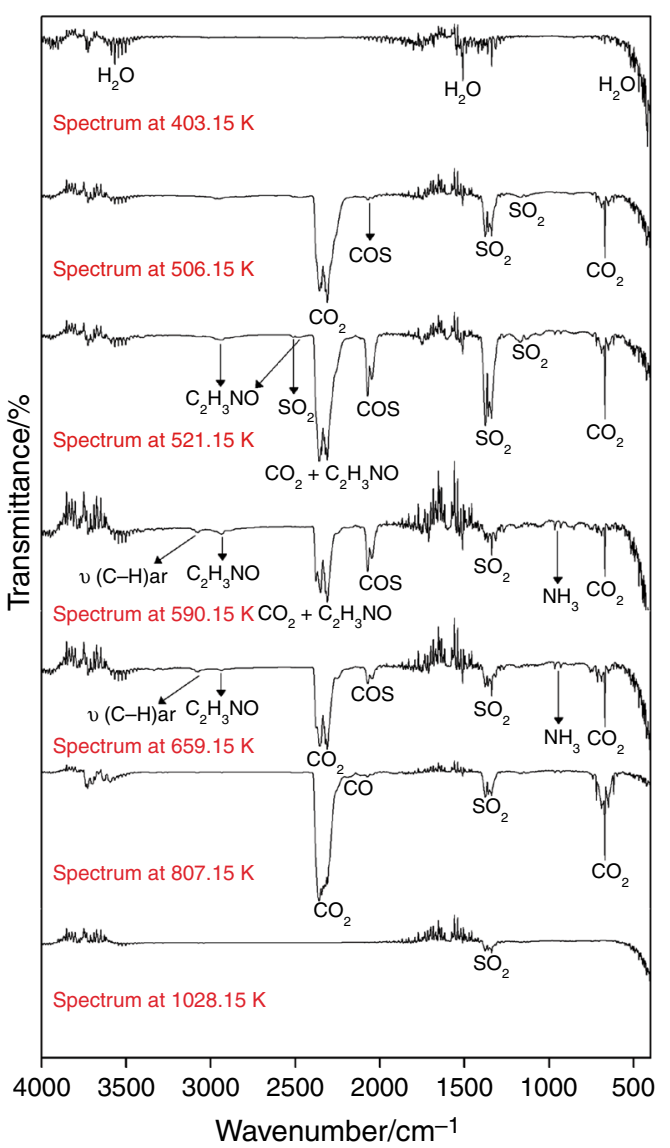

$\left(b^{*}\right)$

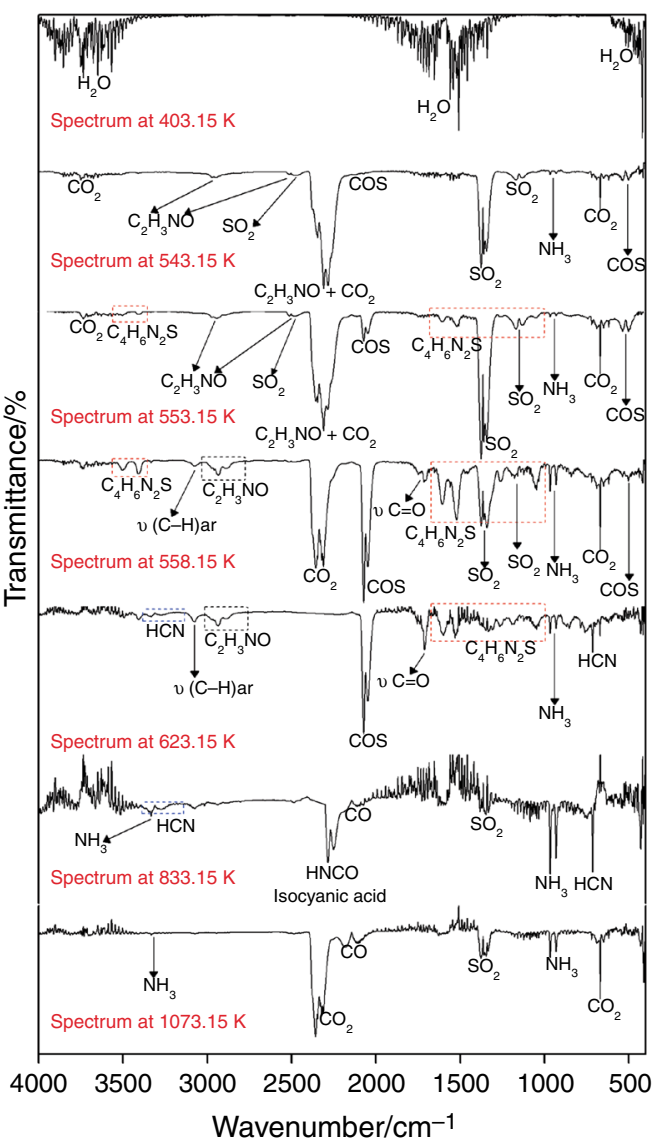

Fig. 6 IR spectra of gaseous products evolved during the thermal decomposition of the manganese complex in air (a) and nitrogen atmosphere (b), as representative of all the compounds

compounds was tested against various bacterial species and the results were good. However, in that study, the authors used solutions with high concentrations of compounds $\left(100 \mathrm{mg} \mathrm{mL}^{-1}\right)$, which would probably be toxic to the human body and therefore not be appropriate for clinical application.

One of the main objectives of justifying the use of metal ion complexes with anti-inflammatory drugs is the possibility of increasing their power. Figure 8 shows the results for the anti-inflammatory activity of the complex $\left[\mathrm{Cu}(\mathrm{Hmel})_{2}\left(\mathrm{H}_{2} \mathrm{O}\right)_{2}\right] \mathrm{H}_{2} \mathrm{O}$ in the paw edema model in rats. The complex does not cause the inhibition of edema at any of the evaluated time intervals, while the standard meloxicam is significantly able to inhibit edema (42, 46 and $52 \%$ of inhibition) at time intervals (2nd, 3rd and 4th hour, respectively). The absence of an anti-inflammatory 

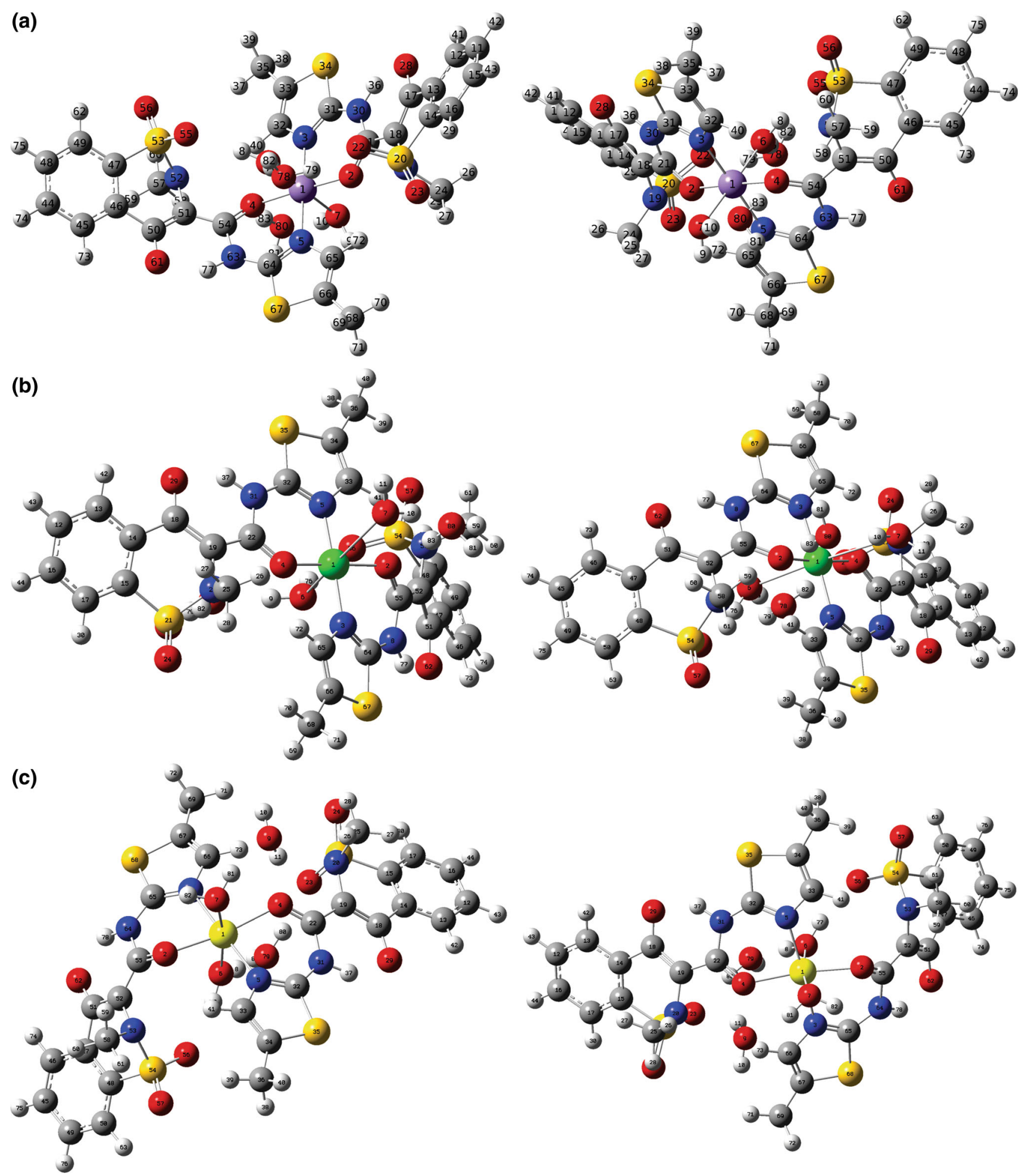

Fig. 7 Theoretical $3 \mathrm{D}$ structures in two different perspectives: a $\left[\mathrm{Mn}(\mathrm{Hmel})_{2}\left(\mathrm{H}_{2} \mathrm{O}\right)_{2}\right] 2 \mathrm{H}_{2} \mathrm{O}, \quad$ b $\quad\left[\mathrm{Ni}\left(\mathrm{Hmel}_{2}\left(\mathrm{H}_{2} \mathrm{O}\right)_{2}\right] 2 \mathrm{H}_{2} \mathrm{O} \quad\right.$ and c $\left[\mathrm{Zn}(\mathrm{Hmel})_{2}\left(\mathrm{H}_{2} \mathrm{O}\right)_{2}\right] 2 \mathrm{H}_{2} \mathrm{O}$

effect of the $\left[\mathrm{Cu}(\mathrm{Hmel})_{2}\left(\mathrm{H}_{2} \mathrm{O}\right)_{2}\right] \mathrm{H}_{2} \mathrm{O}$ complex that is observed in this study may either be due to the absence of intrinsic activity or low absorption of the drug in the gastrointestinal tract (probably caused by the low solubility). If the latter possibility is correct, then if the complex is administered orally, it might be useful to treat colitis. 


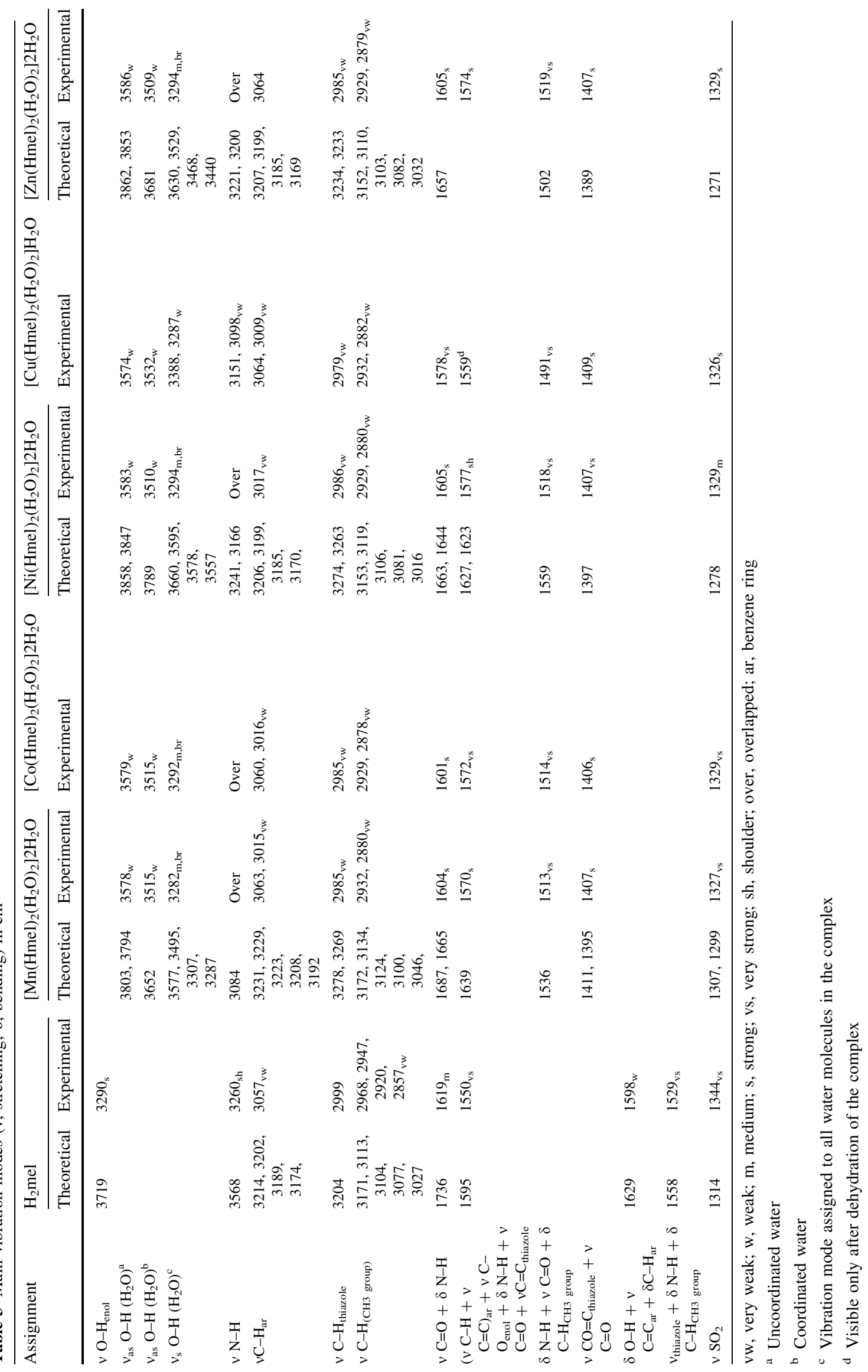




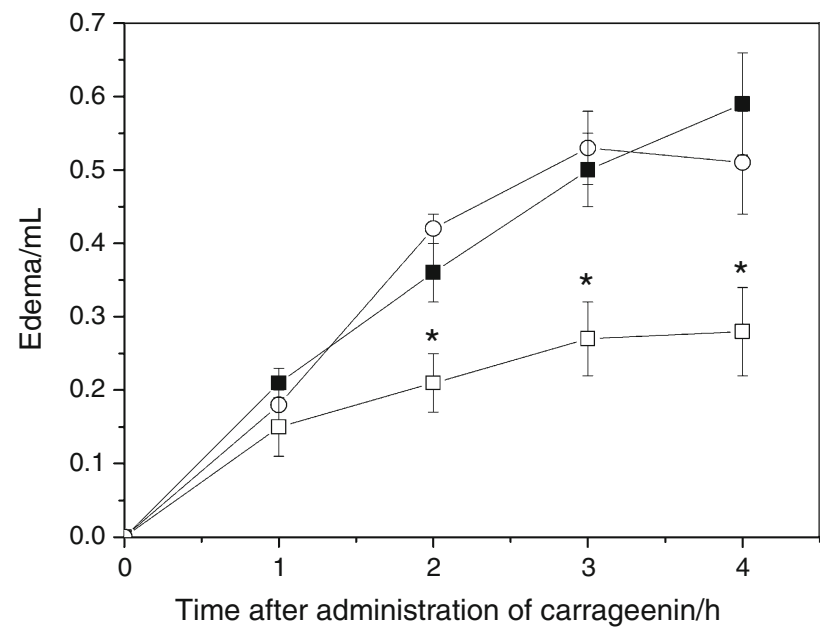

Fig. 8 Inhibition of edema induced by carrageenin: filled square control; open square meloxicam (4 $\mathrm{mg} \mathrm{kg}^{-1}$; p.o.); open circle $\left[\mathrm{Cu}(\mathrm{Hmel})_{2}\left(\mathrm{H}_{2} \mathrm{O}\right)_{2}\right] \mathrm{H}_{2} \mathrm{O}\left(4 \mathrm{mg} \mathrm{kg}^{-1}\right.$; p.o. $)$

Further investigations should be performed to verify this hypothesis.

\section{Conclusions}

Synthesis of meloxicam complexes with $\mathrm{Mn}(\mathrm{II}), \mathrm{Co}(\mathrm{II})$, $\mathrm{Ni}(\mathrm{II}), \mathrm{Cu}$ (II) and $\mathrm{Zn}$ (II) was performed in an aqueous medium following the principles of green chemistry.

Based on the results of the TG curves and elemental analysis, a general formula could be established for the synthesized compounds: $\left[\mathrm{M}(\mathrm{Hmel})_{2}\left(\mathrm{H}_{2} \mathrm{O}\right)_{2}\right] n \mathrm{H}_{2} \mathrm{O}$, where $\mathrm{M}=\mathrm{Mn}(\mathrm{II}), \mathrm{Co}(\mathrm{II}), \mathrm{Ni}(\mathrm{II}) ; \mathrm{Cu}(\mathrm{II})$ and $\mathrm{Zn}(\mathrm{II})$; Hmel = meloxicam and $n=2(\mathrm{Mn}, \mathrm{Co}, \mathrm{Ni}, \mathrm{Zn})$ and $1(\mathrm{Cu})$.

The simultaneous TG/DTG-DTA data provided previously unreported information about the thermal stability and thermal decomposition of these compounds in dynamic air and nitrogen atmospheres.

Evolved gas analysis showed the remarkable influence of the atmosphere (air and $\mathrm{N}_{2}$ ) on the thermal decomposition mechanism of this complex, and it was also possible to identify the main gaseous products of thermal degradation.

The experimental spectroscopic infrared region data and the theoretical calculations suggested that the binding of the meloxicam anion $\left(\mathrm{Hmel}^{-}\right)$to the transition metal ion (M(II)) was performed in a chelating mode through amide oxygen and thiazolyl nitrogen. The similarity between the experimental infrared spectra suggests that all the compounds were coordinated in a similar way, except for the copper complex, which must have had water molecules interacting in a different way in the structure of the compound.
The compounds showed little activity in relation to $S$. aureus. However, this seems to have no relevance regarding clinical applications. It would be interesting to test the activity of these compounds against other species of microorganisms in order to verify their potential.

The $\left[\mathrm{Cu}(\mathrm{Hmel})_{2}\left(\mathrm{H}_{2} \mathrm{O}\right)_{2}\right] \mathrm{H}_{2} \mathrm{O}$ did not show in vivo antiinflammatory activity in the test that was performed. This may have been due to the fact that the complexation of meloxicam with $\mathrm{Cu}^{2+}$ caused the loss of the anti-inflammatory activity or due to non-absorption of the compound by the oral route because of its low solubility.

Acknowledgements The authors would like to thank the FAPESP (Proc. 2013/09022-7), CNPq and CAPES foundations (Brazil). This research was supported by resources supplied by the Center for Scientific Computing (NCC/Grid UNESP) of the São Paulo State University (UNESP), Instituto de Quimica de Araraquara, UNESP Campus de Araraquara and CENAPAD-UNICAMP.

\section{References}

1. Rang HP, Dale MM, Ritter JM, Moore PK. Farmacologia. 5th ed. Rio de Janeiro: Guanabara Koogan; 2003.

2. Sayen S, Carlier A, Tarpin M, Guillon E. A novel copper (II) mononuclear complex with the non-steroidal anti-inflammatory drug diclofenac: structural characterization and biological activity. J Inorg Biochem. 2013;120:39-43.

3. Weder JE, Dillon CT, Hambley TW, Kennedy BJ, Lay PA, Biffin JR, Regtop HL, Davies NM. Copper complexes of non-steroidal anti-inflammatory drugs: an opportunity yet to be realized. Coord Chem Rev. 2002;232:95-126.

4. Sanatkar TH, Hadadzadeh H, Simpson J, Jannesari Z. The meloxicam complexes of $\mathrm{Co}(\mathrm{II})$ and $\mathrm{Zn}(\mathrm{II})$ : synthesis, crystal structures, photocleavage and in vitro DNA-binding. J Mol Struct. 2013;1049:336-44.

5. Dimiza F, Papadopoulos A, Tangoulis V, Psycharis V, Raptopoulou CP, Kessissoglou D, Psomas G. Biological evaluation of cobalt (II) complexes with non-steroidal anti-inflammatory drug naproxen. J Inorg Biochem. 2012;107:54-64.

6. Sharma J, Singla A, Dhawan S. Zinc-naproxen complex: synthesis, physicochemical and biological evaluation. Int $\mathrm{J}$ Pharm. 2003;260:217-27.

7. Oga S, Taniguchi FS, Najjar R, Souza AR. Synthesis, characterization, and biological screening of a copper flurbiprofen complex with anti-inflammatory effects. J Inorg Biochem. 1991;41:45-51.

8. Ribeiro G, Benadiba M, Colquhoun A, Silva DO. Diruthenium (II, III) complexes of ibuprofen, aspirin, naproxen and indomethacin non-steroidal anti-inflammatory drugs: synthesis, characterization and their effects on tumor-cell proliferation. Polyhedron. 2008;27:1131-7.

9. Konstandinidou M, Kourounakis A, Yiangou M, Hadjipetrou L, Kovala-Demertzi D, Hadjikakou S, Demertzis M. Anti-inflammatory properties of diclofenac transition metalloelement complexes. J Inorg Biochem. 1998;70:63-9.

10. Singla AK, Wadhwa H. Zinc-indomethacin complexes: synthesis, physicochemical and biological evaluation in the rat. Int J Pharm. 1995; 120:145-55.

11. Zayed MA, Nour El-Dien FA, Mohamed GG, El-Gamel NEA. Structure investigation, spectral, thermal, X-ray and mass characterization of piroxicam and its metal complexes. Spectrochim Acta Mol Biomol Spectrosc. 2004;60:2843-52. 
12. Defazio S, Cini R. Synthesis, X-ray structural characterization and solution studies of metal complexes containing the anti-inflammatory drugs meloxicam and tenoxicam. Polyhedron. 2003;22:1355-66.

13. Cini R, Tamasi G, Defazio S, Hursthouse MB. Unusual coordinating behavior by three non-steroidal anti-inflammatory drugs from the oxicam family towards copper (II). Synthesis, X-ray structure for copper (II)-isoxicam, -meloxicam and -cinnoxicamderivative complexes, and cytotoxic activity for a copper (II)piroxicam complex. J Inorg Biochem. 2007;101:1140-52.

14. Defazio S, Cini R. Synthesis, X-ray structure and molecular modeling analysis of cobalt (II), nickel (II), zinc (II) and cadmium (II) complexes of the widely used anti-inflamatory drug meloxicam. J Chem Soc, Dalton Trans. 2002;9:1888-97.

15. Tamasi G, Serinelli F, Consumi M, Magnani A, Casolaro M, Cini R. Release studies from smart hidrogels as carriers for piroxicam and copper (II)-oxicam complexes as anti-inflammatory and anticancer drugs. X-ray structures of new copper(II)-piroxicam and isoxicam complex molecules. J Inorg Biochem. 2008;102: 1862-73.

16. Roy S, Banerjee R, Sarkar M. Direct binding of $\mathrm{Cu}$ (II)-complexes of oxicam NSAIDs with DNA backbone. J Inorg Biochem. 2006;100:1320-31.

17. Becke AD. Density-functional thermochemistry.III. The role of exact exchange. J Chem Phys. 1993;98:5648-52.

18. Lee C, Yang W, Parr RG. Development of the colle-salvetti correlation-energy formula into a functional of the electron density. Phys Rev B. 1988;37:785-9.

19. McLean AD, Chandler GS. Contracted Gaussian-basis sets for molecular calculations. 1. 2nd row atoms, $\mathrm{Z}=11-18$. J Chem Phys. 1980;72:5639-48.

20. Raghavachari K, Binkley JS, Seeger R, Pople JA. Self-consistent molecular orbital methods. 20. Basis set for correlated wavefunctions. J Chem Phys. 1980;72:650-4.

21. Frisch MJ, Trucks GW, Schlegel HB, Scuseria GE, Robb MA, Cheeseman JR, Scalmani G, Barone V, Mennucci B, Petersson GA, Nakatsuji H, Caricato M, Li X, Hratchian HP, Izmaylov AF, Bloino J, Zheng G, Sonnenberg JL, Hada M, Ehara M, Toyota K, Fukuda R, Hasegawa J, Ishida M, Nakajima T, Honda Y, Kitao O, Nakai H, Vreven T, Montgomery Jr JA, Peralta JE, Ogliaro F, Bearpark M, Heyd JJ, Brothers E, Kudin KN, Staroverov VN, Kobayashi R, Normand J, Raghavachari K, Rendell A, Burant JC, Iyengar SS, Tomasi J, Cossi M, Rega N, Millam JM, Klene M, Knox JE, Cross JB, Bakken V, Adamo C, Jaramillo J, Gomperts R, Stratmann RE, Yazyev O, Austin AJ, Cammi R, Pomelli C, Ochterski JW, Martin RL, Morokuma K, Zakrzewski VG, Voth GA, Salvador P, Dannenberg JJ, Dapprich S, Daniels AD, Farkas O, Foresman JB, Ortiz JV, Cioslowski J, Fox DJ. Gaussian 09, Revision A.02. Wallingford: Gaussian, Inc.; 2009.

22. Sonnenberg JL, Hada M, Ehara M, Toyota K, Fukuda R, Hasegawa J, Ishida M, Nakajima T, Honda Y, Kitao O, Nakai H, Vreven T, Montgomery Jr. JA, Peralta JE, Ogliaro F, Bearpark M, Heyd JJ, Brothers E, Kudin KN, Staroverov VN, Kobayashi R, Normand J, Raghavachari K, Rendell A, Burant JC, Iyengar SS, Tomasi J, Cossi M, Rega N, Millam NJ, Klene M, Knox JE, Cross JB, Bakken V, Adamo C, Jaramillo J, Gomperts R, Stratmann RE, Yazyev O, Austin AJ, Cammi R, Pomelli C, Ochterski JW, Martin RL, Morokuma K, Zakrzewski VG, Voth GA, Salvador P, Dannenberg JJ, Dapprich S, Daniels AD, Farkas Ö, Foresman JB, Ortiz JV, Cioslowski J, Fox DJ. Gaussian 09. Wallingford: Gaussian, Inc.; 2009.
23. Goodson DZ, Sarpal SK, Wolfsberg M. Influence on isotope effect calculations of the method of obtaining force constants from vibrational data. J Phys Chem. 1982;86:659-63.

24. Schelegel HB. Some practical suggestions for optimizing geometries and locating transition states. In: Juan B, Imre GC, editors. New theoretical concepts for understanding organic reactions. Netherlands: Academic; 1989. pp. 33-53.

25. GaussView, Version 5.0.8, Dennington R, Keith T, Millam, J. Semichem Inc., Shawnee Mission KS, 2000-2008.

26. Suzuki Y, Muraishi K, Ito H. Thermal decomposition of manganese (II) dicarboxylate anhydrides in various atmospheres. Thermochim Acta. 1995;258:231-41.

27. Xu ZP, Zeng HC. Thermal evolution of cobalt hydroxides: a comparative study of their various structural phases. J Mater Chem. 1988;8:2499-506.

28. Silvertein RM, Webster FX, Kiemle DJ. Spectrometric identification of organic compounds. 7th ed. New York: Wiley; 2005.

29. Andersson MP, Uvdal P. New scale factors for harmonic vibrational frequencies using the B3LYP density functional method with the triple basis set6-311 $+\mathrm{G}(\mathrm{d}, \mathrm{p})$. J Phys Chem A. 2005; 109:2937-41.

30. Sundaraganesan N, Ilakiamani S, Dominic Joshua B. FT-Raman and FT-IR spectra, ab initio and density functional studies of 2-amino-4,5-difluorobenzoicacid. Spectrochim Acta A. 2007;67:287-97.

31. Karabacak M, Cinar M, Kurt M, Chinna Babu P, Sundaraganesan N. Experimental and theoretical FTIR and FT-Raman spectroscopic analysis of 1-pyrenecarboxylic acid. Spectrochim Acta, Part A. 2013;114:509-19.

32. Gökce H, Bahceli S. Quantum chemical computations of 1,3phenylene diacetic acid. Spectrochim Acta, Part A. 2011;78: 803-8.

33. Mahmoud WH, Mohamed GG, El-Dessouky MMI. Coordination modes of bidentate lornoxicam drug with some transition metal ions. Synthesis, characterization and antimicrobial and antibreastic cancer activity studies. Spectrochim Acta, Part A. 2014;122:598-608.

34. Chiniforoshan H, Tabrizi L, Hadizade M, Sabzalian MR, Chermahini AN, Rezapour M. Anti-inflammatory drugs interacting with $\mathrm{Zn}$ (II) metal ion based on thiocyanate and azide ligands: synthesis, spectroscopic studies, DTF calculations and antibacterial assays. Spectrochim Acta, Part A. 2014;128:183-90.

35. Fiori ATM, Lustri WR, Magalhães A, Corbi PP. Chemical, spectroscopic characterization and antibacterial activities in vitro of a novel gold(I)-ibuprofen complex. Inorg Chem Commun. 2011;14(5):738-40.

36. Núñez C, Fernández-Lodeiro A, Fernández-Lodeiro J, Carballo J, Capelo JL, Lodeiro C. Synthesis, spectroscopic studies and in vitro antibacterial activity of ibuprofen and its derived metal complexes. Inorg Chem Commun. 2014;2014(45):61-5.

37. Soliman MH, Mohamed GG. Cr(III), Mn(II), Fe(III), Co(II), $\mathrm{Ni}(\mathrm{II}), \mathrm{Cu}(\mathrm{II})$ and $\mathrm{Zn}(\mathrm{II})$ new complexes of 5-aminosalicylic acid: spectroscopic, thermal characterization and biological activity studies. Spectrochim Acta Part A Mol Biomol Spectros. 2013;107:8-15. 